Women's War 



\section{Women's War}

\section{Fighting and Surviving the American Civil War}

\section{Stephanie McCurry}

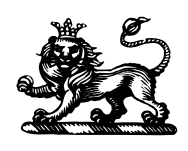

The Belknap Press of

Harvard University Press

Cambridge, Massachusetts

London, England

2019 


\section{Copyright (C) 2019 by Stephanie McCurry \\ All rights reserved \\ Printed in the United States of America}

First printing

Jacket artwork: Detail of Confederates Advancing to the Capture of Disabled Guns, Gaines Mills, by Alfred R. Waud, I862. Courtesy of Library of Congress Prints \& Photographs Division.

Jacket design: Tim Jones

$$
\begin{gathered}
9780674239937 \text { (EPUB) } \\
9780674239944(\mathrm{MOBI}) \\
9780674239920(\mathrm{PDF})
\end{gathered}
$$

The Library of Congress bas cataloged the printed edition as follows:

Names: McCurry, Stephanie, author.

Title: Women's war : fighting and surviving the American Civil War /

$$
\text { Stephanie McCurry. }
$$

Description: Cambridge, Massachusetts : The Belknap Press of Harvard University Press, 2019. | Includes bibliographical references and index. Identifiers: LCCN 201804533I | ISBN 9780674987975 (alk. paper) Subjects: LCSH: United States-History-Civil War, I86I-I865-Women. | Spies_Confederate States of America. | Women spies-Confederate States of America. | Women slaves-United States-History-I9th century. | Fugitive slaves_-United States_-History-I9th century. | Civil-military relations-United States-History-19th century. | Reconstruction (U.S. history, I865-I877)_Georgia. | United States-HistoryCivil War, I86I-I865-Influence.

Classification: LCC E628 .M35 2019 | DDC 973.7082-dc23

LC record available at https://lccn.loc.gov/20I804533I 
For Saoirse 
